\title{
Which Type of Social Capital Matters for Building Trust in Government? Looking for a New Type of Social Capital in the Governance Era
}

\author{
Seunghwan Myeong ${ }^{1, *, \dagger}$ and Hyungjun Seo ${ }^{2, \dagger}$ \\ 1 Department of Public Administration, Inha University, Nam-gu, Incheon 402-751, Korea \\ 2 Department of Global e-Governance, Inha University, Nam-gu, Incheon 402-751, Korea; 22132106@inha.edu \\ * Correspondence: shmyeong@inha.ac.kr; Tel.: +82-032-860-7951 \\ + These authors contributed equally to this work.
}

Academic Editor: Marc A. Rosen

Received: 22 November 2015; Accepted: 29 March 2016; Published: 31 March 2016

\begin{abstract}
When the level of trust in government is low, government cannot effectively provide services, since the policy goals and the process of implementations are not fully understood by the people. This study hypothesizes that the level of trust in government may increase if the level of social capital increases. It also hypothesizes that the impact of social capital on the level of trust in government may differ depending on the type of social capital. The study examined the relationship between the level of trust in government and types of social capital, including bonding social capital and bridging social capital. The result of multiple regression analysis showed that bonding social capital shows a negative relationship with the level of trust in government, while a bridging social capital has a positive relationship with the level of trust in government. In addition, the study examined the variances of the perceptions of each group based on the degree of social cohesion on the level of trust in government by employing ANOVA. It showed that there are no significant differences in bonding social groups, while bridging social capital groups showed variances in their perception of the level of trust in government.
\end{abstract}

Keywords: trust in government; bonding social capital; bridging social capital

\section{Introduction}

The level of trust in government can be increased by promoting collaborative values between government and citizens, which eventually enhances the level of government effectiveness. Public institutions have been granted legitimacy due to the confidence of the citizens, because they gain strength for carrying out the policy [1] (p. 1130), [2]. When the level of trust is gradually increased, the government can actively implement the planned polices based on legitimacy, and it is possible to obtain wider support and consensus in the policy decision-making process. However, when the level of trust is decreased, the government is unable to implement the policies effectively, which may eventually lead to a vicious circle of mistrust.

Despite its significant contribution to the maintenance and development of the country, the level of trust in government by citizens as a whole appears to be very low in polls conducted all over the world since the 1990s. This phenomenon is a common trend in most Western democracies and is not confined to developing countries. Each country may be seen to be reflecting the same trend, which is a recognition of the failure of government to promote government reform, according to previous studies [3]. Even developed countries, such as the United States and the United Kingdom, are making greater efforts to open up the government (Open Government), which ultimately enhances government transparency through the disclosure of the decision-making processes, as well as involving citizens in it. 
Now, a new code is required to handle the social networking services (SNS) era with trust and moral ethics, based on the flow of undistorted and accurate information in which people are assessing the government through visible policies and practice experiences, with appropriate feedback for government services. If governments or political parties fail to show the specific route of the decision-making processes based on factual information, citizens may not trust in them, because the cross-check mechanism is becoming remarkably more sophisticated than in the past. It is not an exaggeration to say that the traditional hierarchies and social capital that were formed in regionalism, school relations and kinship are now in the process of being dismantled by a new social network capital [4].

Previous studies initially focused on the communication aspects of individual and collective social capital, while since the 1990s, there has been an increasing interest in research that shows how social capital affects the whole of society, including democracy, economic development, country's competitiveness [5], policy non-compliance [6] and organizational performance [7]. Social capital can be divided into bonding and a bridging social capital; the former is a confidence in face-to-face relationships (thick trust) and the latter, a shallow reliance on non-face-to-face relationships (thin trust). Korea is generally reported as a more kinship-oriented society, which mainly relies on informal relationships $[2,8]$.

This study asks whether such assumptions and empirical findings in previous studies are indeed still valid, even if it is obvious that a solidarity-based society attribute, such as traditional social relationships, has been a driving force for national development. However, IT powerhouse Korea has changed dramatically in various ways regarding communication and building social relationships through IT revolutions, in that bridging social capital may have a stronger influence on the level of trust in government. Choi [9] stated that sustainability is a major subject of interest in the field of governance and e-governance in response to environments. Choi and Lee [10] emphasized the importance of long-term sustainability in Korea's regional innovation system and suggested that the governance approach can address sustainability. This suggests a new perspective for looking at how social capital is related in reality to the level of trust in government, which can facilitate sustainable governance or e-governance. This study, therefore, will examine to what extent the bonding and bridging social capital affects the level of trust in government. It will also examine the variances of the perception of different groups based on the degree of social cohesion and the level of trust in government. In this research, the interests, conceptual relationships between the level of trust in government and types of social capital, including a bonding social capital and a bridging social capital, will be discussed, as well as examining the possible predictor of social capital in the level of government trust. In addition, the study will examine the variances of the perception of each group based on the degree of social cohesion on the level of trust in government.

\section{Literature Review}

\subsection{Social Capital}

The discussion on social capital was originated by Lyda J. Hanifan in 1916, who insisted that social capital could not only be a valuable asset for increasing the standard of living, but also a method of increasing the level of social welfare in society as a whole [11]. As social capital was considered a development tool for macroscopic units, such as the organization, society, state and the nation, many researchers have focused on the effect of social capital.

Coleman [12] (pp. 100-101) explained that social capital is defined by its function. It is not a single entity, but a variety of different entities having two characteristics in common: they all consist of some aspect of social structure, and they facilitate certain actions of individuals who are within the structure. Putnam [13] (p. 65) defined social capital as "features of social organization such as networks, norms, and social trust that facilitate coordination and cooperation for mutual benefit". Bourdieu [14] defined it as "the aggregate of the actual or potential resources which are linked to 
possession of a durable network of more or less institutionalized relationships of mutual acquaintance or recognition". Bourdieu and Wacquant [15] explained it as the sum of resources, actual or virtual, that accrue to an individual or a group by virtue of possessing a durable network of more or less institutionalized relationships of mutual acquaintance and recognition. In a similar vein, Portes [16] stated that social capital is the ability of actors to secure benefits by virtue of membership in social networks or other social structures. Meanwhile, Fukuyama [17] said that social capital can be defined simply as the existence of a certain set of informal values or norms shared among members of a group that permit cooperation among them. Nahapiet and Ghoshal [18] (p. 422) defined social capital as "the sum of the actual and potential resources embedded within, available through, and derived from the network of relationships possessed by an individual or social unit. Social capital thus comprises both the network and the assets that may be mobilized through that network". Although there are a large number of definitions by researchers, social capital involves three main factors: trust, norm and network.

On the other hand, Putnam [19] classified social capital into two types: "bridging" and "bonding". "Bridging" is a network among people who have heterogeneous social backgrounds, socio-demographic characteristics, and so on. It focuses on the quantity, rather than the quality of relationships. "Bonding" is a network among people who have homogeneous social backgrounds, socio-demographic characteristics, and so on. It focuses on the quality, rather than the quantity of relationships. The bonding type has strong ties inside their own groups, but they exclude other groups. Adler and Kwon [20] (pp. 19-20) categorized social capital in a similar manner to Putnam. The external group, or bridging views, focuses primarily on social capital as a resource that inheres in the social network, tying a focal actor to other actors. In this view, social capital can help explain the differential success of individuals and firms in their competitive rivalry: the actions of individuals and groups can be greatly facilitated by their direct and indirect links to other actors in social networks. The "internal" group, or bonding views, focus on collective actors' internal characteristics. Finally, "both" groups of definitions are worded so as to be neutral on this internal/external dimension. In this study, we will follow Putnam's [19] classification, such as bridging social capital and bonding social capital, to differentiate each effect of social capital.

Table 1 shows previous studies on bonding social capital and bridging social capital. According to previous studies, most researchers argued that a bridging social capital is more positive and more useful for macro-level factors (such as economic well-being, communities and external trust), than a bonding social capital.

Table 1. Previous studies on bonding social capital and bridging social capital.

\begin{tabular}{|c|c|c|}
\hline Research Summary & Research Points & Researchers \\
\hline $\begin{array}{l}\text { Examines the relationship between bonding } \\
\text { social capital and bridging social capital on } \\
\text { South Korea's regionalism. }\end{array}$ & $\begin{array}{l}\text { Bonding type organization strengthens } \\
\text { regionalism, and characteristics of bridging } \\
\text { social capital alleviate regionalism. }\end{array}$ & Lee et al. [21] \\
\hline $\begin{array}{l}\text { Compares how SNS (social network service) } \\
\text { use influences bonding social capital and } \\
\text { bridging social capital. }\end{array}$ & $\begin{array}{l}\text { SNS use has a positive influence on bridging } \\
\text { networks, but none on bonding networks. }\end{array}$ & Choi et al. [22] \\
\hline $\begin{array}{l}\text { Examines the relationship between } \\
\text { corruption and each form of social capital } \\
\text { focusing on OECD countries. }\end{array}$ & $\begin{array}{l}\text { Type IV (Norway, Sweden, Finland, and so } \\
\text { on), which shows high bridging social capital } \\
\text { and low bonding social capital, has higher } \\
\text { integrity than Type V (Turkey, Poland, } \\
\text { Mexico, South Korea, and so on), which } \\
\text { shows low bridging social capital, and high } \\
\text { bonding social capital. }\end{array}$ & Lee [8] \\
\hline $\begin{array}{l}\text { Examines how each form of social capital } \\
\text { worked in the case of Hurricane Katrina in } \\
\text { New Orleans, Louisiana. }\end{array}$ & $\begin{array}{l}\text { Bonding social capital was important for } \\
\text { immediate support, but bridging and linking } \\
\text { social capital offered pathways to longer-term } \\
\text { survival and wider neighborhood and } \\
\text { community revitalization. }\end{array}$ & $\begin{array}{l}\text { Hawkins and } \\
\text { Maurer [23] }\end{array}$ \\
\hline
\end{tabular}


Table 1. Cont.

\begin{tabular}{|c|c|c|}
\hline Research Summary & Research Points & Researchers \\
\hline $\begin{array}{l}\text { Examines how bonding and bridging social } \\
\text { capital are associated with economic } \\
\text { well-being using the National Survey of } \\
\text { Families and Households (NSFH) panel } \\
\text { data in the United States of America (USA). }\end{array}$ & $\begin{array}{l}\text { High bridging social capital had a significant } \\
\text { positive effect on economic well-being, but } \\
\text { bonding social capital had no } \\
\text { significant effect. }\end{array}$ & Zhang et al. [24] \\
\hline $\begin{array}{l}\text { Examines how bonding and bridging social } \\
\text { capital are associated with economic } \\
\text { well-being using General Social Survey } \\
\text { (GSS) data in Canada. }\end{array}$ & $\begin{array}{l}\text { Bridging social capital had a significant } \\
\text { positive relationship with economic } \\
\text { well-being compared to bonding } \\
\text { social capital. }\end{array}$ & Weaver et al. [25] \\
\hline
\end{tabular}

\subsection{Trust in Government}

Evans [1] stated that trust in government can foster government efficacy by increasing cooperative values linking citizens to public agencies. This is because the combination of strong public institutions and organized communities is a powerful tool for development [1]. In the case of trust in government, Hooghe and Stolle (2003) state that: "It seems evident that citizens, who experience this lack of impartiality, will not develop trust in those government institutions that discriminate against them. Furthermore, the observance and experience of political officials and other citizens who promote their own interests by means of corruption or fraud, as well as their own experience of discrimination, prevent the development of not only institutional trust but also trust in other citizens" [26] (p. 242). Additionally, Stolle and Hooghe (2005) argued that "governments can realize their capacity to generate trust only if citizens consider the state itself to be trustworthy. States enable the establishment of contracts in that they provide information and monitor legislation, and enforce rights and rules that sanction lawbreakers, protect minorities and actively support the integration and participation of citizens" [27] (p. 34). Although trust in government is considered the main factor in the sustainability and development of a nation, since 1990, trust in government has declined [3]. Especially in South Korea, according to the formal index, trust in the public area is very low, compared to other developed countries. The report "Society at a Glance 2014" by the OECD shows that South Korea ranked 31st among 32 countries with regard to trust in public institutions. Additionally, Transparency International's Corruption Perceptions Index (CPI), which can predict trust in the state, revealed that South Korea, with a score of 55, ranked 43rd among 175 countries (Denmark ranked first with a score of 92). Trust in government is generally defined as a positive attitude or evaluative intention of government behavior by citizens [28]. Table 2 shows previous studies that analyzed the main factors for trust in government.

Table 2. Previous studies on trust in government.

\begin{tabular}{lll}
\hline \multicolumn{1}{c}{ Research Summary } & \multicolumn{1}{c}{ Research Points } & \multicolumn{1}{c}{ Researchers } \\
\hline $\begin{array}{l}\text { Assembling social capital studies in empirical } \\
\text { and theoretical aspects. }\end{array}$ & $\begin{array}{l}\text { The generation of social capital has a strong } \\
\text { relationship with government actions. }\end{array}$ & $\begin{array}{l}\text { Hooghe and } \\
\text { Stolle [26] }\end{array}$ \\
\hline $\begin{array}{l}\text { Comparing to the generation and the effect } \\
\text { of social capital at the micro-level } \\
\text { and macro-level. }\end{array}$ & $\begin{array}{l}\text { Government should provide citizens with } \\
\text { equal access and an equal chance for trust } \\
\text { in government. }\end{array}$ & $\begin{array}{l}\text { Stolle and } \\
\text { Hooghe [27] }\end{array}$ \\
\hline $\begin{array}{l}\text { Examining the relationship between trust in } \\
\text { government and factors of informatization } \\
\text { (information perception and purpose of } \\
\text { information use). }\end{array}$ & $\begin{array}{l}\text { High positive information perception and high } \\
\text { active purpose of information use had a } \\
\text { significant positive effect on trust } \\
\text { in government. }\end{array}$ & Myeong et al. [29] \\
\hline $\begin{array}{l}\text { Examining how interpersonal trust, } \\
\text { participation in associations and political } \\
\text { participation affect trust in government. }\end{array}$ & $\begin{array}{l}\text { Interpersonal trust, participation in associations } \\
\text { (vertical and horizontal) and passive political } \\
\text { participation had a significant positive effect on } \\
\text { trust in government. }\end{array}$ & Park et al. [2] \\
\hline
\end{tabular}


Table 2. Cont.

\begin{tabular}{|c|c|c|}
\hline Research Summary & Research Points & Researchers \\
\hline $\begin{array}{l}\text { Comparing how migration status and religion } \\
\text { (Muslims and Christians) affect trust in } \\
\text { government in Britain. }\end{array}$ & $\begin{array}{l}\text { Migrants have more positive trust in } \\
\text { government than natives, and Muslims have } \\
\text { more positive trust in government } \\
\text { than Christians. }\end{array}$ & Maxwell [30] \\
\hline $\begin{array}{l}\text { Examining determinants of trust in government } \\
\text { in three Scandinavian countries (Denmark, } \\
\text { Finland, Sweden), and three east Asian nations } \\
\text { (South Korea, China, Japan). }\end{array}$ & $\begin{array}{l}\text { Participation in policy making, policy } \\
\text { preferences, political efficiency, network and } \\
\text { interpersonal trust had a significant positive } \\
\text { effect on trust in government. }\end{array}$ & Park and Kim [5] \\
\hline $\begin{array}{l}\text { Examining how the factors of religion (religious } \\
\text { affiliation, denomination and religious } \\
\text { attendance) affect trust in government. }\end{array}$ & $\begin{array}{l}\text { Religious affiliation had a significant positive } \\
\text { effect on trust in government, while religious } \\
\text { attendance had a negative effect. }\end{array}$ & Lee [31] \\
\hline $\begin{array}{l}\text { Examining how two facets of } \\
\text { e-democracy-transparency and } \\
\text { interactivity-affect citizens' trust in } \\
\text { government in the case of Internet use. }\end{array}$ & $\begin{array}{l}\text { Internet use is positively associated with } \\
\text { transparency satisfaction, but negatively } \\
\text { associated with interactivity satisfaction, and } \\
\text { both interactivity and transparency are } \\
\text { positively associated with trust in government. }\end{array}$ & $\begin{array}{l}\text { Welch and } \\
\text { Hinnant [32] }\end{array}$ \\
\hline $\begin{array}{l}\text { Comparing trust in government, before and } \\
\text { after } 9 / 11 \text {. }\end{array}$ & $\begin{array}{l}\text { When people focus on domestic issues (like } \\
\text { crime, etc.), trust in government could decline, } \\
\text { but conversely, when people focus on } \\
\text { international issues (like the } 9 / 11 \text { attack), trust } \\
\text { in government could be increased. }\end{array}$ & Chanley [33] \\
\hline $\begin{array}{l}\text { Examining determinants of trust in the } \\
\text { governments of Japan and South Korea. }\end{array}$ & $\begin{array}{l}\text { Government performance regarding the } \\
\text { economy, controlling political corruption, } \\
\text { quality of public services, crime and attention } \\
\text { to citizen input are significantly associated with } \\
\text { trust in government in both Japan and } \\
\text { South Korea. }\end{array}$ & Kim [34] \\
\hline
\end{tabular}

The researchers suggested various determinants for trust in government. Hooghe and Stolle, Park et al., Park and Kim, especially, used social capital as factors for trust in government. In actuality, social capital is not the only determinant for trust in government, but we assumed that social capital is a valuable asset in contemporary low trust society. As already mentioned, Korea shows one of the lowest levels of trust, although it is well developed. This is why we focused on social capital for trust in government.

\section{Research Design}

\subsection{Theoretical Model and Hypothesis}

The theoretical model in Figure 1 was employed to describe the relationship between social capital and trust in government. As defined in the previous chapter, social capital can be explained as the sum of resources embedded within and derived from the network of relationships possessed by an individual, local communities and social activities [29,32,35]. Specifically, the emergence and widespread adoption of new networks and data management technologies among citizens and government has broken new ground, by enabling municipal government officials to break out of their top-down and rule-driven structures [35]. If individuals in a city favorably perceive networking environments, then they are likely to actively collect data and to participate in an engaged form of networked communities, which is related to the formation of trust in government. The theoretical model was used to examine the relationship between bonding social capital and bridging social capital and the level of trust in government, which was considered to potentially vary across people. Demographic variables, including sex, age, education and income, are being controlled to examine variances across people. In this regard, the following hypotheses are proposed:

H1: Bonding social capital has a positive effect on trust in government.

$\mathrm{H} 2$ : Bridging social capital has a positive effect on trust in government. 


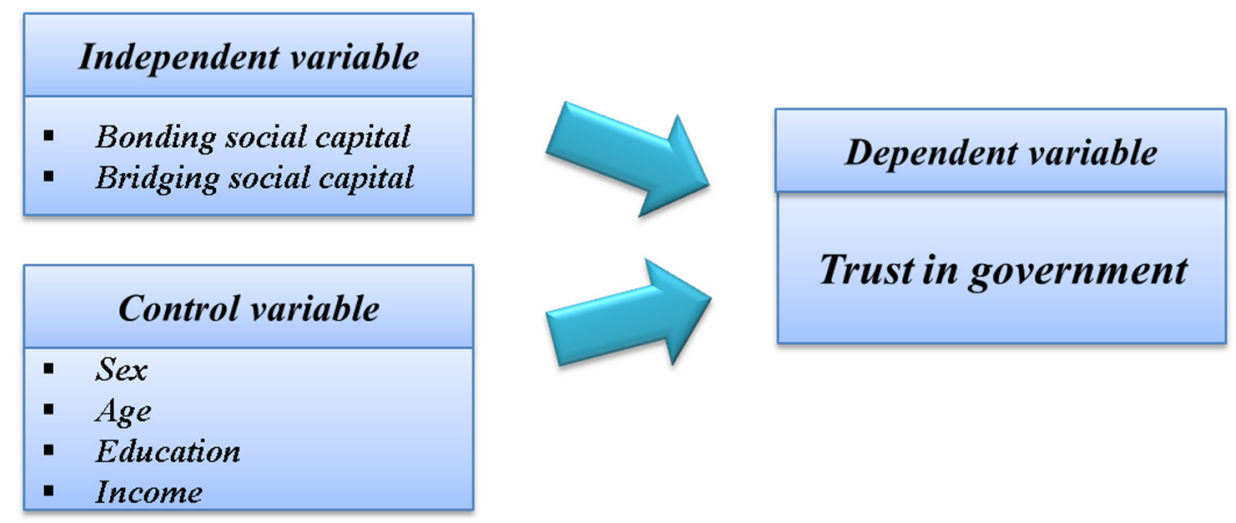

Figure 1. Theoretical model.

\subsection{Data Collection and Measurement}

Table 3 shows the demographic profile of respondents. Data were collected from a national survey conducted from 10 October to 31 October 2013. A pilot survey was conducted to assess the reliability and validity of the questionnaire, which was sent to a total of 350 randomly-sampled individuals, who reside in Seoul Metropolitan City, Incheon Metropolitan City, and the Gyeong-gi Province, by e-mail. The metropolitan area was assessed as having top-quality information systems and programs in the Local Informatization Evaluation Reports (Korean Association for Local Informatization, 2013). The organizational size is reported by many studies as the critical factor influencing the process of decision-making or the implementation of electronic government projects in United States (U.S.) cities [36] (pp. 35-39). They maintain that higher degrees of horizontal and vertical differentiation in larger organizations often bring an increased need for control and coordination within an organization. Therefore, citizens in a metropolitan city area might more actively use an advanced network and data management technologies in the formation of trust in municipal government. The effect of networking environments could be perceived more diversely by citizens.

Table 3. Demographic profile of respondents $(N=350)$.

\begin{tabular}{|c|c|c|c|}
\hline Variables & Index & Frequency (No. of Individuals) & $\%$ \\
\hline \multirow[b]{2}{*}{ Sex } & Male & 173 & 49.4 \\
\hline & Female & 177 & 50.6 \\
\hline \multirow{5}{*}{ Age } & $20 \mathrm{~s}$ & 67 & 19.1 \\
\hline & $30 \mathrm{~s}$ & 75 & 21.4 \\
\hline & $40 \mathrm{~s}$ & 78 & 22.3 \\
\hline & $50 s$ & 66 & 18.9 \\
\hline & 60 s and over & 64 & 18.3 \\
\hline \multirow{3}{*}{ Area of residence } & Seoul & 145 & 41.4 \\
\hline & Incheon & 40 & 11.4 \\
\hline & $\begin{array}{l}\text { Gyeong-gi } \\
\text { Province }\end{array}$ & 165 & 47.1 \\
\hline \multirow{4}{*}{ Education } & Middle school & 28 & 8.0 \\
\hline & High school & 185 & 52.9 \\
\hline & College & 131 & 37.4 \\
\hline & Graduate school & 6 & 1.7 \\
\hline
\end{tabular}

\subsection{Measurement Data and Construct Validity}

For the constructs of "social capital" and "trust in government", measurement instruments developed in the previous studies, as shown in Table 4, were adopted and measured using a five-point 
Likert-type scale, ranging from "strongly disagree" (one) to "strongly agree" (five). Table 5 shows the measurement methods for variables and the rotated pattern of factors. A principal component analysis was conducted using items for each variable.

Table 4. Measurement instruments for social capital and trust in government.

\begin{tabular}{|c|c|c|}
\hline Variables & Measurement Items & Previous Studies. \\
\hline $\begin{array}{l}\text { Bonding social } \\
\text { capital: (Perception } \\
\text { of strong-tie } \\
\text { relationships) }\end{array}$ & $\begin{array}{ll}\text { - } & \text { Having people who can give advice } \\
\text { - } & \text { First, request advice from close people } \\
\text { - } & \text { Lending money to acquaintances } \\
\text { - } & \text { Considering close people as a reference group } \\
\text { - } & \text { Sharing and discussing with close people } \\
\text { - } & \text { Feeling a sense of importance among close people }\end{array}$ & \multirow{2}{*}{$\begin{array}{l}\text { Onyx and Bullen } \\
\text { [38], Lee [8], Lee } \\
\text { [31], Choi et al. [22], } \\
\text { Zhang et al. [24] }\end{array}$} \\
\hline $\begin{array}{l}\text { Bridging social } \\
\text { capital: (Perception } \\
\text { of weak-tie } \\
\text { relationships) }\end{array}$ & $\begin{array}{ll}\text { - } & \text { Believing most people in our society } \\
\text { - } & \text { Helping strangers } \\
\text { - } & \text { Volunteer work will give benefits in the long term } \\
\text { - } & \text { Accountability for the poor class } \\
\text { - } & \text { Inclination to join a civic group } \\
\text { - } & \text { Inclination to join political groups } \\
- & \text { Interaction with government using social network } \\
& \text { services (SNS) }\end{array}$ & \\
\hline $\begin{array}{l}\text { Trust in } \\
\text { government: } \\
\text { (Perceived } \\
\text { satisfaction of civic } \\
\text { services) }\end{array}$ & $\begin{array}{ll}\text { - } & \text { Perceived general trust } \\
\text { - } & \text { Perceived professional competence } \\
\text { - } & \text { Perceived content service quality } \\
\text { - } & \text { Perceived service efficiency } \\
\text { - } & \text { Perceived voluntary efforts for service upgrade } \\
\text { - } & \text { Perceived adequacy of information provision } \\
\text { - } & \text { Perceived improvement of old procedures }\end{array}$ & $\begin{array}{l}\text { Myeong et al. [41] } \\
\text { Christensen and } \\
\text { Lægreid [40] }\end{array}$ \\
\hline
\end{tabular}

Table 5. Measurement instruments and rotated pattern of factors (varimax rotation).

\begin{tabular}{|c|c|c|c|c|c|c|}
\hline Variable & Measurement Items & Factor $\mathbf{L}$ & ading & $\begin{array}{l}\text { Cronbach's } \\
\text { Alpha }\end{array}$ & $\begin{array}{l}\text { Kaiser-Meyer- } \\
\text { Olkin (KMO) }\end{array}$ & $\begin{array}{l}\text { Bartlett } \\
\text { Sphericity }\end{array}$ \\
\hline \multirow{6}{*}{$\begin{array}{c}\text { Bonding } \\
\text { social capital }\end{array}$} & Having people who can give advice & 0.672 & & \multirow{6}{*}{$0.771^{* * *}$} & \multirow{6}{*}{0.833} & \multirow{6}{*}{479.954} \\
\hline & First, request advice from close people & 0.660 & & & & \\
\hline & Lending money to acquaintances & 0.627 & & & & \\
\hline & Considering close people as a reference group & 0.683 & & & & \\
\hline & Sharing and discussing with close people & 0.709 & & & & \\
\hline & Feeling a sense of importance among close people & 0.790 & & & & \\
\hline \multirow{7}{*}{$\begin{array}{l}\text { Bridging } \\
\text { social capital }\end{array}$} & Believing most people in our society & 0.261 & 0.612 & \multirow{7}{*}{$0.738^{* * *}$} & \multirow{7}{*}{0.759} & \multirow{7}{*}{512.270} \\
\hline & Helping strangers & 0.326 & 0.712 & & & \\
\hline & Volunteer work will give benefits in the long term & -0.028 & 0.734 & & & \\
\hline & Accountability for the poor class & 0.632 & 0.264 & & & \\
\hline & Inclination to join a civic group & 0.846 & 0.15 & & & \\
\hline & Inclination to join a political group & 0.868 & 0.07 & & & \\
\hline & $\begin{array}{l}\text { Interaction with government using social network } \\
\text { services (SNS) }\end{array}$ & 0.111 & 0.595 & & & \\
\hline \multirow{7}{*}{$\begin{array}{l}\text { Trust in } \\
\text { government }\end{array}$} & Perceived general trust & 0.785 & & \multirow{7}{*}{$0.833^{* * *}$} & \multirow{7}{*}{0.905} & \multirow{7}{*}{1089.501} \\
\hline & Perceived professional competence & 0.763 & & & & \\
\hline & Perceived content service quality & 0.753 & & & & \\
\hline & Perceived service efficiency & 0.761 & & & & \\
\hline & Perceived voluntary efforts & 0.724 & & & & \\
\hline & Perceived adequacy of information provision & 0.792 & & & & \\
\hline & Perceived improvement of old procedures & 0.795 & & & & \\
\hline
\end{tabular}

${ }^{*} p<0.05 ;{ }^{* *} p<0.01 ; * * * p<0.001$ (in factor loading, some figures that are highlighted in gray indicate that bridging social capital could be loaded into two factors). 
First, the independent variables are bonding social capital and bridging social capital based on strong-tie and weak-tie relationships. Bonding social capital is a kind of relationship with family and close friends, while bridging social capital is a relationship with people who are outside their own immediate bonds [22,37]. Putnam, a well-known social capital researcher, suggested participation in community organizations, participation in public work, voluntary work, informal behavior and social trust as measurement items to indicate social capital [11]. Onyx and Bullen [38] suggest measurement items, such as participation in the local community, social agency or proactivity in a social context, feelings of trust and safety, neighborhood connections, family and friend connections, tolerance of diversity, value of life, and so on. Grootaeat et al. [39] at the World Bank suggests the Integrated Questionnaire for the Measurement of Social Capital (SC-IQ), which includes groups and networks, trust and solidarity, collective action and cooperation, information and communication, social cohesion and inclusion and empowerment and political action to compare each degree of social capital in a global dimension. Many researchers have similar conceptions for measuring instruments.

Secondly, the dependent variable is the level of trust in government. Most research studies on trust in government have measured this by asking the level of trust in government institutions, including parliament, cabinet, the judicial branch, the legislative branch and public institutions $[2,5,30-32,34]$. Some researchers utilize perceptions of civic service for measuring instruments [29,40]. In this study, we use perceived satisfaction with civic service as a surrogate measure to indicate the level of trust in government. The perceived satisfaction with civic services was examined to extend the literature to the perception of government services in the context of Gov 3.0, a newly-emerging phenomenon. Gov 3.0 is a national administrative system that strengthens the role of individuals by redesigning administrative methods and processes, based on highly intelligent ICT applications and social connections. In Gov 3.0, the government shares information and knowledge with firms, citizens and global communities and provides common platforms that can produce value-added democratic exchanges between social members [39].

A total of six items of perception of civic services are used for measuring the level of trust in government, including general trust, professional competence, content service, efficient service, upgrade of services, provision of various information and improvement of old procedures. Table 4 shows our measurement items based on previous studies.

The reliability of the items was assessed using Cronbach's alpha (Cronbach's $\alpha$ ). As shown in Table 4, all items are loaded on their proposed factors, satisfying the Kaiser-Meyer-Olkin (KMO) threshold of 0.60 according to Kaiser [42]. Cronbach's alpha for all items exceeded 0.60. Devellis [43] suggested that there is insufficient reliability, if Cronbach's alpha for a scale is less than 0.60 .

As shown in Table 5, first bonding social capital was measured by a total of six items. Cronbach's $\alpha$ was $0.771 ; \mathrm{KMO}$ was 0.833 ; and Bartlett sphericity was 479.954 . The bonding social capital was loaded onto one factor. Secondly, bridging was measured by a total of seven items. Cronbach's $\alpha$ was 0.738; KMO was 0.759; and Bartlett sphericity was 512.270. The bonding social capital was loaded onto one factor. The bridging social capital was loaded onto two factors. We named each factor as a "passive bridging social capital" and "active social capital", because factors of active social capital (social accountability, civic group and political group) showed a more active intention for participation in social groups, compared to the factor of a passive social capital, which indicates a positive perception and intentions for society in general. Finally, trust in government was measured by a total of seven items. Cronbach's $\alpha$ was 0.833; KMO was 0.905; and Bartlett Sphericity was 1089.501. The trust in government was loaded onto one factor.

Table 6 shows the results of Pearson's correlation coefficient analysis. According to factor score by factor analysis, we conducted the correlation analysis among bonding social capital, passive bridging social capital, active bridging social capital and trust in government. As a result, all dependent variables were significant in terms of the level of trust in government. Specifically, active social capital and passive social capital show a strong relationship with trust in government, compared to bonding social capital. We assumed that passive bridging social capital might have a stronger influence on 
the level of trust in government, because it can be shown in a daily open and networked life and within a horizontal relationship. This means that awareness of unity and trust in community can be an important determinant factor in the level of trust in government.

Table 6. Pearson's correlation coefficient analysis.

\begin{tabular}{ccccc}
\hline Variables & $\begin{array}{c}\text { Bonding Social } \\
\text { Capital }\end{array}$ & $\begin{array}{c}\text { Active Bridging } \\
\text { Social Capital }\end{array}$ & $\begin{array}{c}\text { Passive Bridging } \\
\text { Social Capital }\end{array}$ & $\begin{array}{c}\text { Trust in } \\
\text { Government }\end{array}$ \\
\hline Bonding social capital & 1 & $0.131^{*}$ & $0.433^{* *}$ & $0.163^{* *}$ \\
Active bridging social capital & $0.131^{*}$ & 1 & 0.00 & $0.277^{* *}$ \\
Passive bridging social capital & $0.433^{* *}$ & 0.00 & 1 & $0.472^{* *}$ \\
Trust in government & $0.163^{* *}$ & $0.277^{* *}$ & $0.472^{* *}$ & 1 \\
\hline & ${ }^{*} p<0.05 ; * * 0.01 ; * * *<0.001$.
\end{tabular}

\section{Analysis Results and Discussion}

\subsection{Results of a Multiple Regression Analysis}

Table 7 shows the multiple regression results, with the independent variable and the control variable. The coefficient of determination in the regression model was 39.3 percent, indicating the model to be significant $(F$-value $=11.930, p<0.001)$.

Table 7. Results of a multiple regression analysis.

\begin{tabular}{|c|c|c|c|c|}
\hline \multicolumn{3}{|c|}{ Items } & B & $\mathbf{t}$ \\
\hline \multirow{3}{*}{ Independent variable } & \multirow{3}{*}{\multicolumn{2}{|c|}{$\begin{array}{c}\text { Bonding social capital } \\
\text { Active bridging social capital } \\
\text { Passive bridging social capital }\end{array}$}} & $-0.112 *$ & -2.253 \\
\hline & & & $0.311^{* * *}$ & 6.915 \\
\hline & & & $0.501^{* * *}$ & 10.316 \\
\hline \multirow{15}{*}{ Control variable } & Sex & Female & 0.207 * & 2.272 \\
\hline & \multirow{4}{*}{ Age } & $20 \mathrm{~s}$ & $-0.583^{* *}$ & -3.435 \\
\hline & & $30 \mathrm{~s}$ & -0.247 & -1.406 \\
\hline & & $40 \mathrm{~s}$ & $-0.379^{*}$ & -2.349 \\
\hline & & $50 \mathrm{~s}$ & -0.273 & -1.68 \\
\hline & \multirow{3}{*}{ Education } & High school & -0.344 & -1.741 \\
\hline & & College & -0.214 & -0.939 \\
\hline & & Graduate school & -0.408 & -1.023 \\
\hline & \multirow{7}{*}{ Income } & 1 to 2 million KRW & $1.163 *$ & 2.278 \\
\hline & & 2 to 3 million KRW & 0.945 & 1.878 \\
\hline & & 3 to 4 million KRW & $1.389 * *$ & 2.750 \\
\hline & & 4 to 5 million KRW & $1.418^{* *}$ & 2.794 \\
\hline & & 5 to 6 million KRW & $1.501 * *$ & 2.888 \\
\hline & & 6 to 7 million KRW & $1.182 *$ & 2.216 \\
\hline & & 7 million KRW and over & $1.683^{* *}$ & 3.165 \\
\hline \multicolumn{3}{|c|}{ Invariable } & -0.858 & -1.825 \\
\hline \multicolumn{3}{|c|}{$R^{2}$} & \multicolumn{2}{|c|}{0.393} \\
\hline \multicolumn{3}{|c|}{ adjusted $R^{2}$} & \multicolumn{2}{|c|}{0.361} \\
\hline \multicolumn{3}{|c|}{ F-value } & \multicolumn{2}{|c|}{$11.930^{* * *}$} \\
\hline
\end{tabular}

${ }^{*} p<0.05 ;{ }^{* *} p<0.01 ;{ }^{* * *} p<0.001$. Sex, age, education and income are nominal variables, so we converted the nominal scale to dummy variables to conduct multiple regression analysis. Male in sex, 60 s and over in age, middle school in education and under 1 million KRW in income are each of the classification variables.

Firstly, as shown in Table 7, bonding social capital $(B=-0.112, p<0.05)$ has a negative relationship with trust in government, while active bridging social capital $(B=0.311, p<0.001)$, and passive bridging social capital $(B=0.501, p<0.001)$ have a positive relationship with trust in government. 
Secondly, in terms of the control variable, Female $(B=0.207, p<0.05)$ in sex was positively related with trust in government, while the ages of $20 \mathrm{~s}(B=-0.583, p<0.01)$ and $40 \mathrm{~s}(B=-0.379, p<0.05)$ were negatively related to trust in government at the level of significance. In terms of the level of income, respondents between 1 to 2 million KRW $(B=1.163, p<0.05), 3$ to 4 million KRW $(B=1.389$, $p<0.01), 4$ to 5 million KRW $(B=1.418, p<0.01), 5$ to 6 million KRW $(B=1.501, p<0.01), 6$ to 7 million KRW $(B=1.182, p<0.05)$ and 7 million KRW and over $(B=1.683, p<0.01)$ were positively related to trust in government. This study involved exploratory research, and we categorized ages and incomes as narrower than traditional survey studies, because they may show different patterns of relations in an SNS society, which are more complicated and dynamic, depending on age groups and incomes.

The result shows that bonding social capital negatively affects trust in government, and it is contrary to the results of the previous studies [2,5]. Park et al. [2] and Park and Kim [5] found that bonding social capital positively influences trust in government. We assumed that the reason for our result differing from previous studies is that we employed measurement items for indicating trust in government based on civil services. On the other hand, it supports the arguments by Putnam [44] and Fukuyama [17], since they found that bonding social capital, including regionalism, school relations and kinship, has a negative relationship with formal trust. Putnam [44] argued that the critical factor responsible for the low level of Southern Italy's social integration, compared to that of the North, is their strong blood ties and lack of horizontal relations in local communities.

Thirdly, the result shows that the two bridging social capitals are positively related to trust in government. This supports the results of previous studies, which reported the positive effects of bridging social capital $[29,32,35]$. The bridging social capital enables people to make wide networks, join horizontal associations and evaluate government services. As Putnam [44] mentioned, thin trust and joining horizontal associations, like bridging social capital, may provide more of a visible ground of networking and communication paths for deliberation in the process of consensus building. Interestingly, the passive bridging social capital was more positively related to the level of trust in government than the active social capital. It can be explained that the activities through citizen groups and political parties that participated as active bridge social capital may depend on their own ideologies and belief systems, which are not strongly relevant to the formation of trust in government. They act according to judgments based on ideology and belief systems, which hinders the correct evaluation of government services based on the facts and data gathered in an everyday life cycle.

\subsection{ANOVA Results}

Table 8 shows the differences in the perception of trust in government among two types of social capital groups. Also Figure 2 shows Distribution chart along with each social capital group type.

Table 8. Differences in the level of trust in government between two social capital groups.

\begin{tabular}{|c|c|c|c|c|c|}
\hline Index & $\begin{array}{l}\text { Perception of Trust in } \\
\text { Government among Each Group }\end{array}$ & Number & Mean & Standard Deviation & $F$-Value \\
\hline \multirow{3}{*}{$\begin{array}{l}\text { Bonding social } \\
\text { capital }\end{array}$} & Low & 14 & 2.87 & 0.92 & \multirow{3}{*}{2.674} \\
\hline & Middle & 239 & 3.19 & 0.57 & \\
\hline & High & 97 & 3.28 & 0.75 & \\
\hline \multirow{3}{*}{$\begin{array}{l}\text { Bridging social } \\
\text { capital }\end{array}$} & Low & 43 & 2.59 & 0.79 & \multirow{3}{*}{$32.473^{* * *}$} \\
\hline & Middle & 287 & 3.25 & 0.55 & \\
\hline & High & 20 & 3.76 & 0.67 & \\
\hline
\end{tabular}




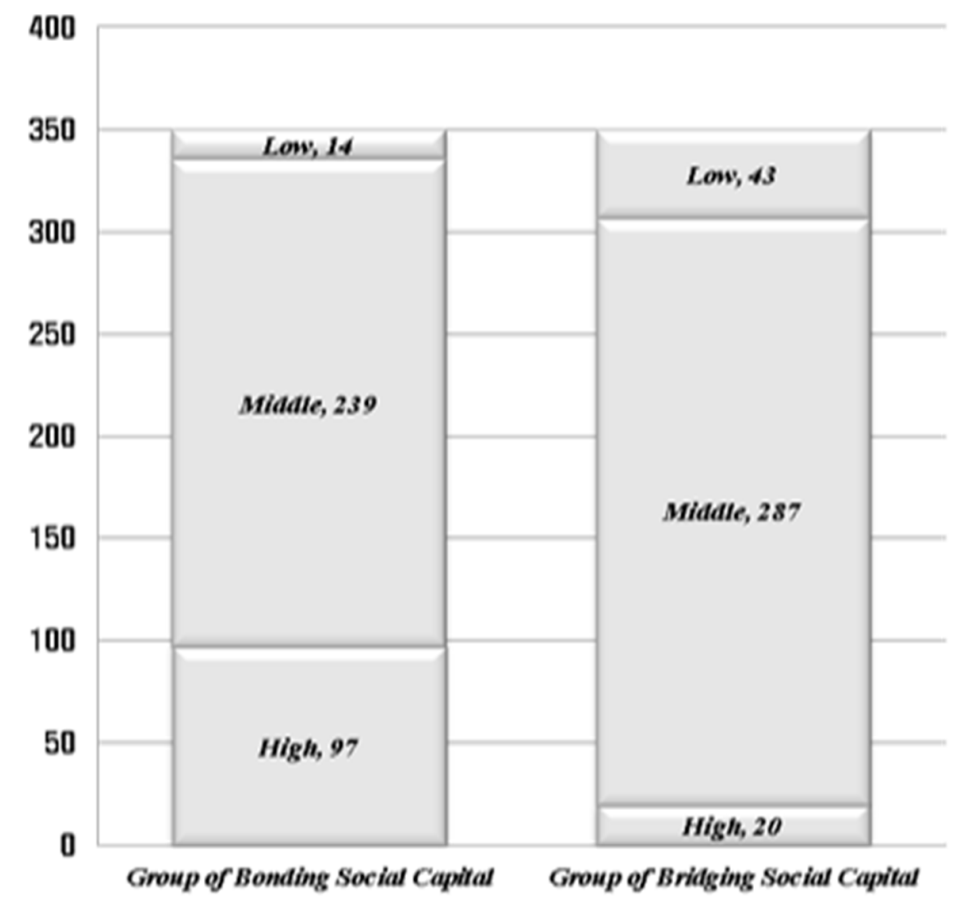

Figure 2. Distribution chart along with each social capital group type.

Firstly, even if in bonding social capital groups, the high group (3.28) showed the highest level of trust in government, followed by middle (3.19) and low (2.87), it is not acceptable at the level of significance $(F=2.674)$.

Secondly, in terms of bridging social capital groups, the high group (3.76) showed the highest level of trust in government, followed by middle (3.25) and low (2.59), and it is significantly different among bridging social capital groups $(F=32.473, p<0.001)$. Additionally, to find which groups were significant, we conducted a Scheffe post hoc comparison. All three groups are significantly different in their perception of trust in government.

As shown by the ANOVA results, bonding social capital has no influence on trust in government, while bridging social capital is a determinant factor in causing a difference of trust in government, similar to the results of the multiple regression analysis above.

\section{Policy Implication and Conclusions}

As shown in the previous chapter, a low level of trust in government that is not rooted in the bridging or the weak-tie social capital may weaken the government's authority to efficiently implement or deliver civic services in the era of the SNS society. If people's low level of trust in government policies is caused by a lack of ability in government to read people's minds and eventually resulted in blocking the normal process of feedback with support, it might cause a so-called vicious cycle of a low trust society [45] (p. 2). This phenomenon serves to demonstrate that the traditional policy-making processes have neglected to listen to citizens' voices and to recognize a deliberative stage in the policy-making process.

This study validates the effectiveness of government social capital of trust and helps to derive the policy implications for trust in government. In particular, by separating the social capital into two different types, it evaluates the impact on confidence in the government's social capital.

Firstly, the regression results show that passive bridging social capital has a stronger influence on the level of trust in government, compared to groups in active social capital. We assume that active forms of bridging social capital, including volunteering in non-governmental organizations and political activities, may represent social interests in a traditional democratic society. As mentioned 
above, ideologies and belief systems may have more influence on the level of trust in government, as they have been developed in more closed relations, with observance and experiences, especially in relations with government institutions and political parties. The facts and data may help to increase the level of government trust when they support good governance and services with evidence. Otherwise, the development of not only institutional trust, but also trust in a whole society is prevented. If citizens trust governments less, based on the past experiences and discrimination, then they might not actively use IT-based information and data, even if the government makes great efforts to show its well-organized and sophisticated government portals and mobile content.

Secondly, the results of the multiple regression analysis imply that bonding social capital negatively influences trust in government, while bridging social capital factors have a significant impact on trust in government. Thus, the second hypothesis (H2) could be accepted. In addition, the ANOVA results showed no statistically-significant differences for the case of bonding social capital on trust in government. On the other hand, the high group has the highest level of trust in government in bridging social capital, implying that government may need to pay more attention to the groups of bridging social capital, who are more sociable, communicative and active in gathering information made available by government efforts to provide a bridging ground or platform. In that public-oriented or citizen-oriented platform, which is operated by the factual data and big data analysis, citizens may experience a new type of government service, moving away from the traditional top-down and rule-driven structures [35].

Thirdly, the result from the female group, which showed higher levels of government trust, is an interesting finding, but it is difficult to say females have a more positive perception of government activities in general. It is also interesting that the age categories of 20 s and 40 s show a stronger level of distrust in government at the level of significance. As reported in the 2015 Pew survey, the younger generations generally have less confidence in the government's directions (Pew Research Center, 2015) [46]. It is still questionable that people of all age groups show a negative perception of government trust, although not statistically significant.

Finally, the result showing the higher the income, the higher the levels of government trust implies that it may have been extracted from the sample of the study population of the metropolitan area of Seoul, Incheon and Gyeong-gi Province. Citizens in this area could get more benefits from the government's policies and institutions, and the quality of government services is much higher, compared to the other regions. They also have an advantage in the gathering of information and its utilization in a more advanced network environment. These results suggest that government policy for open data and sharing may have a positive impact on the increase in personal income and the development of a local economy. Opportunities for universal services for the poor need to be enlarged in order to reduce the gap between information rich and poor, because the digital divide leads to a welfare gap in a knowledge and information society. As previous studies suggested (Park and Kwon, 2013; Van Dijk, 2006), multidimensional aspects of the digital divide are needed to conceptualize the magnitude of digital gaps in social, economic, cultural and political relationships, going beyond its familiar definition $[47,48]$. They also pointed out that digital divide research has suffered from a lack of theory in the past 10 years, which has remained at a descriptive level, by limitedly emphasizing the demographics of income, education, age, sex and ethnicity. As Stolle and Hooghe (2005) were quoted as having argued in an earlier chapter, even citizens experiencing well-designed government services, who experience a lack of impartiality, will not be confident in those government organizations that discriminate against them [27]. This raises issues regarding the mechanisms that link interpersonal and institutional trust in future studies.

Based on the above discussion and policy implications, the study provides policy recommendations for decision makers, or public officials in governmental and municipal organizations.

Firstly, governments need to make decisions based on accurate data and procedures that support the norms and legitimacy of policy implementation in a legal system. In order to promote confidence among citizens, governments and communities, policy-making processes need to be changed based 
on facts and impartial procedures for convincing all members of society to strongly support policy instruments and implementation. In the SNS and big data era, the level of trust in government will be lower if the level of uncertainty is high, regarding what the government is really doing, and it retains all norms and laws that do not work effectively. The capacity of individuals for information management and control has already passed beyond the limit of government, with the use of more sophisticated and customer-oriented private distribution and trading platforms (such as Facebook, Google, Amazon, etc.). The current cycle of disconnected information flow, caused by each department and silo organization in the government sector, will worsen, if it keeps perpetuating the existing policy processes and operating mechanisms, without examining the rapidly changing environments. As the previous studies argued, even in a nation that has a well-developed e-government, a high level of government trust cannot be guaranteed, although many governments mistakenly expect that e-government services will promote trust in government. Therefore, many governments fail to transform their e-government into e-governance in which a local-based innovation system is needed to develop trust-building mechanisms in retaining users for their online public services (Choi and Lee, 2009; Teo et al., 2003) [10,49].

Secondly, the authoritarian and top-down approaches in the process of policy making and implementation need to be revised. Governments need to find a new mediator or supporter to restore the ecosystem of the local community, as individuals and local communities are now easily able to control the flow of information through which people are assessing government policies, through more visible and data-oriented policy information, as well as a huge volume of cross-check feedbacks and open dialogues. For the sustainability of local communities or municipalities, the role of bridging social capital needs to be carefully examined and studied among researchers and policy communities. Even if it is obvious that bonding social capital has been a driving force for national development, Korea has dramatically changed its methods of building social relationships through advanced network technologies, and therefore, bridging-social capital as a policy middle layer may have a greater influence on the level of trust in government.

Finally, efforts to develop a transparent society through the disclosure of government information and data tailored for building an open government should be continuously expanded. We need to carefully look at the adoption of big data and the technical progress of the Internet of Things (IoT), which is enabling people to visualize the impact of government policies. Therefore, efforts for visualizing the potential of bridging social capital should be continued in order to build a positively-circulating ecosystem for maintaining the sustainability of a nation or a local community.

Acknowledgments: This work was supported by the Inha University in South Korea. This paper used a data set and partially adopted a theoretical framework in authors' article, "Review of a Relationship between Social Capital and Trust in Government: Focusing on Bonding Social Capital And Bridging Social Capital" published in the Korean Journal of Policy Science.

Author Contributions: Seunghwan Myeong (co-first author/correspondent author) designed a research framework and wrote the paper with editing; Hyungjun Seo (co-first author) updated a literature review and conducted a data analysis.

Conflicts of Interest: The authors declare no conflict of interest.

\section{References}

1. Evans, P. Government action, social capital and development: Reviewing the evidence on synergy. World Dev. 1996, 24, 1119-1132. [CrossRef]

2. Park, H.B.; Lee, H.C.; Jo, Y.S. An Analysis on the properties and determinants of trust in government in Korea. Korean Public Adm. Rev. 2003, 37, 45-66.

3. Nye, J., Zelikow, P., King, D., Eds.; Why Americans Mistrust Government; Harvard University Press: Cambridge, MA, USA, 1997.

4. Myeong, S.H. Smart Electronic Government; Yulgok Book Press: Seoul, Korea, 2015.

5. Park, H.B.; Kim, Y.H. Trust in government and its impact factors in three Scandinavian countries and three East Asian nations. Korean J. Public Adm. 2014, 23, 1-34. 
6. Ha, S.G. A study on the effect of social capital on policy non-compliance. Korean J. Policy Sci. 2014, 18, 131-157.

7. Lee, H.W.; Park, H.B.; Jun, J.Y. Personnel management and influence analysis of social capital on the organizational performance in local governments. Korean J. Policy Sci. 2007, 11, 127-151.

8. Lee, J.J. A Comparative Study on the Relationship between Social Capital and Corruption Among Countries. In Proceedings of the Korean Association for Public Administration Spring Conference, Seoul, Korea, 25 April 2008; KPAR: Jeon-ju, Korea, 2008.

9. Choi, Y. Green management of logistics enterprises and its sustainable performance in Korea. Afr. J. Bus. Manag. 2012, 6, 1475-1482.

10. Choi, Y.; Lee, E.Y. Optimizing risk management for the sustainable performance of the regional innovation system in Korea through metamediation. Hum. Ecol. Risk Assess. 2009, 15, 270-280. [CrossRef]

11. Lee, D.W.; Jung, G.Y.; Park, J.; Chae, S.B.; Han, J. The Third Capital; Samsung Economical Research Institute: Seoul, Korea, 2009.

12. Coleman, J.S. Foundations of Social Theory; Harvard University Press: Cambridge, MA, USA, 1990; pp. $100-101$.

13. Putnam, R.D. Bowling alone: America's declining social capital. J. Democr. 1995, 6, 65-78. [CrossRef]

14. Bourdieu, P. The Forms of Capital. In Handbook of Theory and Research for the Sociology of Education; Richardson, J., Ed.; Greenwood: New York, NY, USA, 1985.

15. Bourdieu, P.; Wacquant, L.J.D. An Invitation to Reflexive Sociology; University of Chicago Press: Chicago, IL, USA, 1992.

16. Portes, A. Social capital: Its origins and applications in modern sociology. Annu. Rev. Sociol. 1998, $24,1-24$. [CrossRef]

17. Fukuyama, F. Social capital and the modern capitalist economy: Creating a high trust workplace. Stern Bus. Mag. 1997, 4, 1-16.

18. Nahapiet, J.; Ghoshal, S. Social capital, intellectual capital, and the organizational advantage. Acad. Manag. Rev. 1998, 23, 242-266.

19. Putnam, R. Bowling Alone; Touchstone Books: New York, NY, USA, 2000.

20. Adler, P.S.; Kwon, S.W. Social capital: Prospects for a new concept. Acad. Manag. Rev. 2002, 27, 17-40.

21. Lee, H.W.; Lee, J.H.; Hahn, Y.B. Different influences of social capital on regionalism: Bonding and bridging social capital. Korean Polit. Sci. Rev. 2011, 45, 149-171.

22. Choi, M.H; Park, M.G; Lee, H.J. The Effect of SNS Use on Bridging and Bonding Networks. In Proceedings of the Korean Association for Public Administration Spring Conference, Seoul, Korea, 25 April 2013; KPAR: Seoul, Korea, 2013; pp. 213-228.

23. Hawkins, R.L.; Maurer, K. Bonding, bridging and linking: How social capital operated in New Orleans following Hurricane Katrina. Bri. J. Soc. Work 2010, 40, 1777-1793. [CrossRef]

24. Zhang, S.; Anderson, S.G.; Zhan, M. Differentiated impact of bridging and bonding social capital on economic well-being: An individual level perspective. J. Soc. Soc. Welfare 2011, 38, 119.

25. Weaver, R.D.; McMurphy, S.M.; Habibov, N.N. Analyzing the impact of bonding and bridging social capital on economic well-being: Results from Canada's general social survey. Sociol. Spectr. 2013, 33, 566-583. [CrossRef]

26. Hooghe, M., Stolle, D., Eds.; Generating Social Capital: Civil Society and Institutions. In Comparative Perspective; Palgrave: New York, NY, USA, 2003.

27. Stolle, D.; Hooghe, M. Conflicting approaches to the study of social capital. Ethic. Perspect. 2005, 10, $22-45$. [CrossRef]

28. Easton, D. A Systems Analysis of Political Life; Wiley: New York, NY, USA, 1967.

29. Myeong, S.H.; Park, J.Y.; Kwon, Y.M.; Lee, B.K. A study on the effects of information perception and purpose of information use on trust in government. Inform. Policy 2012, 19, 25-44.

30. Maxwell, R. Trust in government among British Muslims: The importance of migration status. Polit. Behav. 2010, 32, 89-109. [CrossRef]

31. Lee, S.J. The effect of religion on trust in government. Korean Public Adm. Rev. 2010, 44, 99-119.

32. Welch, E.W.; Hinnant, C.C. Internet use, transparency, and interactivity effects on trust in government. In Proceedings of the 36th Annual Hawaii International Conference on System Sciences, Big Island, HI, USA, 6-9 January 2003.

33. Chanley, V.A. Trust in government in the aftermath of 9/11: Determinants and consequences. Polit. Psycholo. 2002, 23, 469-483. [CrossRef] 
34. Kim, S. Public trust in government in Japan and South Korea: Does the rise of critical citizens matter? Public Admin. Rev. 2010, 70, 801-810. [CrossRef]

35. Goldsmith, S.; Crawford, S. The Responsive City: Engaging Communities Through Data-Smart Governance; Jossey-Bass: San Francisco, CA, USA, 2014.

36. Moon, M.J. Can IT Help Government to Restore Public Trust? Declining Public Trust and Potential Prospects of IT in the Public Sector. In Proceedings of the 36th Annual Hawaii International Conference on System Sciences, Hawaii, HI, USA, 6-9 January 2003.

37. ONS (Office for National Statistics). Social Capital: A Review of the Literature. Social Analysis and Reporting Division Office for National Statistics. Available online: http://www.ons.gov.uk/ons/guide-method/ user-guidance/social-capital-guide/the-social-capital-project/social-capital-a-review-of-the-literature.pdf (accessed on 26 March 2016).

38. Onyx, J.; Bullen, P. Measuring social capital in five communities. J. Appl. Behav. Sci. 2000, 36, $23-42$. [CrossRef]

39. Grootaert, C.; Narayan, D.; Jones, V.N.; Woolcock, M. Integrated Questionnaire for the Measurement of Social Capital; The World Bank Social Capital Thematic Group: Washington, DC, USA, 2003.

40. Christensen, T.; Lægreid, P. Trust in government: The relative importance of service satisfaction, political factors, and demography. Public Perform. Manag. Rev. 2005, 28, 487-511.

41. Myeong, S.H.; Hur, C.H. A study on change of e-Government and paradigm based on Gov 3.0 through shift of smart society. In Proceedings of the Korean Association for Policy Studies Spring Conference, Jeonju, Korea, 13 April 2012; KPSR: Seoul, South Korea, 2012; pp. 325-341.

42. Kaiser, H.F. An index of factorial simplicity. Psychometrika 1974, 39, 31-36. [CrossRef]

43. DeVellis, R.F. Scale Development: Theory and Applications (Applied Social Research Methods); Sage Publications: Thousand Oaks, CA, USA, 2011.

44. Putnam, R. Making Democracy Work: Civic Traditional in Modern Italy; Princeton University Press: Princeton, NJ, USA, 1993.

45. Lee, M.-H.; Jung, Y.-D. A Study on the Public Trust in Government in Korea for Enhancing the national Competitiveness; Korea Institute of Public Administration: Seoul, Korea, 2013.

46. Pew Research Center. Beyond Distrust: How Americans View Their Government. Available online: http:/ / www.people-press.org/files/2015/11/11-23-2015-Governance-release.pdf (accessed on 26 March 2016).

47. Park, J.Y.; Kwon, Y.M. New stratification perspective on the digital divide: A four-scale analysis model. Int. J. eGov. Netw. 2013, 1, 24-44.

48. Van Dijk, J.A. Digital divide research, achievements and shortcomings. Poetics 2006, 34, 221-235. [CrossRef]

49. Teo, T.S.; Srivastava, S.C.; Jiang, L. Trust and electronic government success: An empirical study. JMIS 2003, 25, 99-131. [CrossRef]

(C) 2016 by the authors; licensee MDPI, Basel, Switzerland. This article is an open access article distributed under the terms and conditions of the Creative Commons by Attribution (CC-BY) license (http://creativecommons.org/licenses/by/4.0/). 